\title{
Primary Appendicitis Epiploicae Mimicking Acute Abdomen: Report Of Two Cases
}

\section{Akut Karını Taklit Eden Primer Epiploik Apandisit: İki Olgu Sonumu}

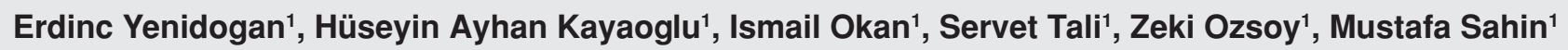

${ }^{1}$ Gaziosmanpaşa Üniversitesi, Tıp Fakültesi, Genel Cerrahí Anabilim Dalı, Tokat, Türkiye

\section{ÖZET}

Primer epiploik apandisit nadir görülen bi durumdur. Burada aku batın bulgularıyla karşımıza çıkan 2 adet olguyu sunmak istedik. Heriki hastaya da şüpheli akut batın bulgularından dolayı bilgisayarlı batın tomografisi çekildi. BT' de kolon segmentlerinin serozal yüzeyindeki apandiks epiploikalarda enfeksiyon saptandı. Hastalara konservatif yaklaşımla, analjezik ve antibiyotik tedavisi başlandı. Semptomlarda 1 hafta içerisinde gerileme oldu. Preoperatif BT bulguları ile konservatif tedavi verilebilir ve gereksiz cerrahinin önüne geçilebilir. Bilgisayarlı batın tomografisi ile erken radyolojik değerlendirme tanıda anahtar role sahip olup heriki hastada da gereksiz cerrahiden kaçınılmasına olanak sağlamıştır.

Anahtarkelimeler: Epiploik apandisit, bilgisayarlı batın tomografisi, konservatif tedavi

\section{ABSTRACT}

Primary appendicitis epiploicae is a rare condition. Here, we present two cases, both with clinical signs of acute abdomen. Two patients with dubious findings of acute abdomen underwent abdominal CT. Both CT revealed appendicitis epiploicae on the serosal surface of colonic segments. Both patients received conservative treatment with pain medication, antibiotics and symptoms subsided within a week. Preoperative CT findings confirming the conservative medical management with $\mathrm{CT}$ findings can prevent unnecessary surgery. Early radiologic examination with an abdominal CT scan is key in making the diagnosis and potentially avoiding unnecessary surgery in such cases.

Key words: Appendicitis epiploicae, abdominal computer tomography, conservative treatment, 


\section{INTRODUCTION}

Primary appendicitis epiploicae is a rare intraabdominal condition resulting from appendices epiploicae inflammation due to the infarction, torsion or thrombosis (1). Appendices epiploicae are small pouches of fat protruding from the serosal surface of colon throughout caecum to rectosigmoid. These structures are in anterior and posterior rows parallel to the taenia coli of the colon and supplied by single artery and vein (2). Epiploic appendigitis is predominantly seen over the age of forty and rarely seen in patients younger than 19 years. It is almost unknown in children and the gender distribution is equal between male and female (3). Most cases occur on the sigmoid colon (4). Inflamation of these structures can lead to acute abdominal pain and mimics a variety of intraabdominal inflammation such as appendicitis, diverticulitis and cholecystitis. Here, we present the management of two patients with appendices epiploicae stressing the prompt diagnosis to avoid unnecessary surgery.

\section{CASES}

\section{Case 1}

A 38 year-old man with a two-day history of colicky left lower abdominal pain. Laboratory and ultrasonic findings were normal. There were no symptoms of obstruction, nausea and vomiting. The physical examination revealed local tenderness and positive rebound in the left lower quadrant, but no general defence was detected. Axillary fever was $37.1^{\circ} \mathrm{C}$, and the rectal examination was normal. CT revealed a $20 \mathrm{~mm}$ fat density lesion with surrounding inflammatory changes at proximal anterior sigmoid colon. The diagnosis of appendicis epiploicae was made. The patient treated conservatively with analgesics pain medication, antibiotics with Ceftriaxon (Iesef, I.E. Ulagay, Istanbul,Turkey) 1 gr , 2 times each day and symptoms subsided within a week and patient was discharged.

\section{Case 2}

A 42 year-old man with one-day history of colicky right lower abdominal pain mimicking as acute appendicitis. The pain was sudden in onset and severe in intensity. It started from the right iliac fossa and remained localized without any radiation. The abdominal examination showed tenderness in the right iliac fossa with rebound tenderness but no guarding or rigidity. The patient also had a low-grade fever $\left(37.4^{\circ} \mathrm{C}\right)$, which was continuous. The patient had significant anorexia. There were no urinary or bowel complaints. There was no significant history of similar pain and the patient had enjoyed good general health before. Although laboratory and ultrasonic findings were normal, CT revealed an oval fatty $15 \mathrm{~mm}$ mass with central streaky densities adjacent to the serosal surface of caecum. The diagnosis of appendicis epiploicae was made and the patient treated conservatively with analgesics pain medication, antibiotics with Ceftriaxon (lesef, I.E. Ulagay, Istanbul,Turkey) $1 \mathrm{gr}, 2$ times each day and symptoms subsided within a week. Patient was discharged after 1 week without any symptoms or complaints.

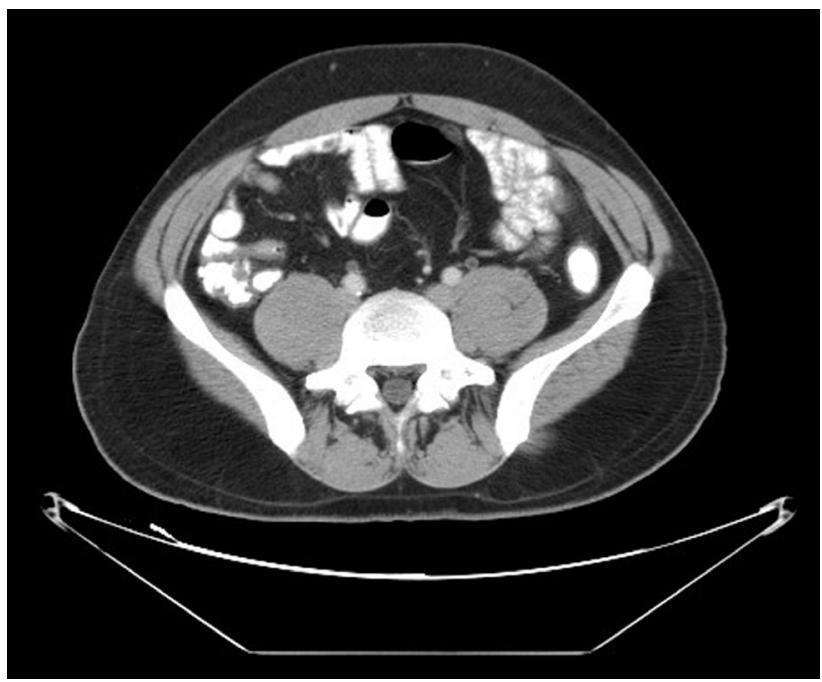

Figure 1. Primary appendicitis epiploica in the anterior proximal of the sigmoid colon.

Informed Consent: This article does not include patient identification information. So there is no need ratification. 


\section{DISCUSSION}

Epiploic appendigitis is an intraabdominal inflammatory pathology of fatty appendages of colon. The patients present with a sharp and atypical pain localized in the lower abdomen, mimicking the signs of peritoneal irritation invoked by appendicitis and diverticulitis. The pain might be colicky or constant in nature and it is usually present for less than a week. Although localized tenderness and guarding are present, rebound is unusual. The temperature and white cell count are sometimes only minimally elevated, otherwise normal.

Most cases of appendicitis epiploicae are caused by torsion which comprises or strangulates the blood supply. When the torsion and subsequent infarction occur insidiously, the patient may experience strong and welllocalized pain. Torsion of the appendix epiploicae carries importance since it usually mimics acute appendicitis $(5,6)$. Khizer et al. reported a child with torsion of appendix epiploicae presenting as acute right iliac fossa pain in abdomen. After the surgery, histopathology was consistent with gangrenous appendix epiploicae (7). It was reported that epiploic appendigitis may be expected to be found in nearly $1 \%$ of patients who were suspected to have acute appendicitis (8). Golash and Wilson reported only eight cases of acute epiploic appendagitis among 1,320 cases of acute abdominal pain (9).

If epiploic appendigitis involves the caecum, the differential diagnosis should include acute appendicitis, regional enteritis, ovarian torsion, salpingoophoritis, typhillitis and perityphillitis. It might mimic acute cholecystitis if proximal part of transverse colon is involved and ovarian torsion if caecum or sigmoid colon is involved.

The diagnosis is rarely performed preoperatively and is often confused with acute appendicitis (1). Majority of cases are diagnosed intraoperatively. A careful history and physical examination are crucial for the preoperative diagnosis to avoid unnecessary surgery. Recently the routine use of CT scan for acute abdominal conditions even for appendicitis has increased the detection of epiploic appendigitis
(4). Similarly, CT scan has been found to be useful for assessment in patients managed conservatively. Normal epiploic appendages are adipose structures that have fat attenuation on CT and in normal cases can not be distinguished from retroperitoneal fat. However, if these structures have inflammation or surrounding intraperitoneal fluid, as in the case of epiploic appendigitis, they may then be visualized on CT (3). CT scan shows a whirling pattern of fatty streaks within the greater omentum (10). A review of literature suggests that the presence of hyperechoic noncompressible ovoid structure near the colonic wall with the absence of blood flow on vigilant sonographic assessment of the abdomen provides the clue to diagnosis (1). Other imaging modalities like ultrasonography (US) may also be useful for diagnosis of epiploic appendigitis. An abdominal US usually shows localized omental thickening (5). Magnetic resonance $(M R)$ is rarely used for diagnosis.

If appendigitis epiploicae diagnosed preoperatively, the treatment is mainly conservative with antibiotics, analgesics and fluid supplementation (1). If an epiploic appendigitis was found in surgery, excision with seromuscular inversion of the affected portion of gut is the best strategy of treatment. If appendix is found to be normal during surgery, inflammation of the appendix epiploicae should be considered. Furthermore, laparoscopy is an excellent diagnostic and therapeutic option in the management of epiploic appendigitis. It allows inspection of the entire abdominal cavity, and ensures that less common causes of abdominal pain are correctly diagnosed and treated. Unal et al. reported a 20-year-old previously appendectomized patient in which torsion of an appendix epiploicae, originating from the sigmoid colon, led to the development of acute abdomen signs in the right lower quadrant. They used CT scan for pre-operative diagnosis and treated the patient with laparoscopy and concluded that laparoscopy offers a minimally invasive tool to simultaneously inspect the abdominal cavity, assess the pelvic mass diagnosis, and treat the patient (5). In our cases, laboratory and ultrasonic findings were normal. 
Epiploic appendigitis is often confused with diverticulitis of the sigmoid colon but can mimic acute appendicitis when it occurs on the right side and poses a diagnostic dilemma. Epiploic appendigitis may also mimic acute cholecystitis if proximal part of transverse colon is involved and ovarian torsion if caecum or sigmoid colon is involved. In our cases, CT revealed an oval fatty mass with central streaky densities adjacent to the serosal surface of caecum. Both patients received conservative treatment with pain medication, antibiotics and symptoms subsided within a week.

\section{CONCLUSION}

Although diagnostic laparoscopy is an excellent tool making the correct diagnosis in such cases, conservative medical management with $\mathrm{CT}$ findings might prevent unnecessary surgery. Early radiologic examination in dubious cases of acute appendicitis with either US or $\mathrm{CT}$ is key in making preoperative diagnosis and potentially avoiding unnecessary surgery in such cases. If a preoperative diagnosis is made, conservative treatment with antibiotics and analgesics seems to be safe. Attempts should be made to confirm the diagnosis preoperatively so that a trial of conservative treatment can be given.

We declare that none of the authors listed in this manuscript have any financial or other conflicts of interest to disclose.

\section{REFERENCES}

1. Hurreiz HS, Madavo CM. Torsion of an epiploic appendix mimicking acute appendicitis. Saudi Med J. 2005;26(12):2003-4.

2. Sand M, Gelos M, Bechara FG, Sand D, Wiese TH, Steinstraesser $\mathrm{L}$, et al. Epiploic appendagitis--clinical characteristics of an uncommon surgical diagnosis. BMC Surg. 2007;7:11.

3. Christianakis E, Paschalidis N, Filippou G, Smailis D, Chorti M, Rizos S, et al. Cecal epiploica appendix torsion in a female child mimicking acute appendicitis: a case report. Cases J. 2009;2:8023.

4. Sing AK, Gervais DA, Hahn PF, Sagar P, Mueller PR, Noveline RA. Acute epiploic appendagitis and its mimics. Radiographics. 2005;25(6):1521-34.

5. Unal E, Yankol Y, Sanal T, Haholu A, Buyukdogan V, Ozdemir Y. Laparoscopic resection of a torsioned appendix epiploica in a previously appendectomized patient.
Surg Laparosc Endosc Percutan Tech. 2005;15(6):371-3.

6. Hapuarachchi KS, Courtney ED, Gergely S, Tang TY. Torsion of parietal-peritoneal fat mimicking acute appendicitis: a case report. J Med Case Rep. 2009;3:6980.

7. Khizer M, Ram S, Khan AM. A rare cause of right iliac fossa pain. J Indian Assoc Pediatr Surg. 2009;14(1):345.

8. Van Breda Vriesman AC, Puylaert JB. Epiploic appendagitis and omental infarction: pitfalls and look-alikes. Abdom Imaging. 2002;27(1):20-8.

9. Golash V, Willson PD. Early laparoscopy as a routine procedure in the management of acute abdominal pain: a review of 1,320 patients. Surg Endosc. 2005;19(7):882-5.

10. Kim J, Kim Y, Cho OK, Rhim H, Koh BH, Kim YS, et al. Omental torsion: CT features. Abdom Imaging. 2004;29(4):502-4. 